\title{
NEW FILARIAL NEMATODE \\ FROM JAPANESE SEROWS (NAEMORHEDUS CRISPUS: BOVIDAE) CLOSE TO PARASITES FROM ELEPHANTS
}

\author{
UNI S.***, BAIN O.**, AGATSUMA T.***, KATSUMI A.****, BABA M.******, YANAI T.******* \& TAKAOKA H.********
}

\section{Summary:}

A new onchocercid species, Loxodontofilaria caprini n. sp. (Filarioidea: Nematoda), found in subcutaneous tissues of 37 (33\%) of 112 serows (Naemorhedus crispus) examined in Japan, is described. The female worm had the characteristics of Loxodontofilaria, e.g., the large body size, well-developed esophagus with a shallow buccal cavity, and the long tail with three caudal lappets. The male worm of the new species, which was first described in the genus, had unequal length of spicules, 10 pairs of pre- and post-caudal papillae, and three terminal caudal lappets. Deirids were present in both sexes. Among four species of the genus Loxodontofilaria: one from the hippopotamus and three from the Elepantidae, L. caprini n. sp. appears close to L. asiatica Bain, Baker \& Chabaud, 1982, a subcutaneous parasite of Elephas indicus in Myanmar (Burma). However, L. caprini n. sp. is distinct from L. asiatica in that the Japanese female worm has an esophagus half as long and the microfilariae also half as long with a coiled posterior. The microfilariae were found in the skin of serows. The new parasite appears to clearly illustrate a major event in the evolution of onchocercids: the host-switching. This might have occurred on the Eurasian continent, where elephantids and the lineage of rupicaprines diversified during the Pliocene-Pleistocene, or in Japan, into which some of these hosts migrated.

KEY WORDS : Loxondontofilaria caprini n. sp., Onchocercidae, Naemorhedus crispus, serow, Caprinae, Bovidae, elephant, host-switching, Japan.
Résumé : Une nouvelle filaire (Nematoda) Chez le SEROW DU JAPON, NAEMORHEDUS CRISPUS (BOVIDAE), PROCHE DE PARASITES D'ÉLÉPHANTS

Une nouvelle filaire sous-cutanée Loxodontofilaria caprini n. sp., Onchocercidae, est décrite chez Naemorhedus crispus, Caprinae, au Japon. Elle a les caractères de Loxondontofilaria, définis sur la femelle, seul sexe connu jusqu'à présent chez ce genre: corps de grande taille, œesophage développé mais absence de capsule buccale, queve longue, avec trois languettes terminales. Le mâle de L. caprini n. sp. a des spicules inégaux, 10 paires de papilles caudales, dont quatre paires précloacales, et trois languettes caudales. Deirides présentes dans les deux sexes. Parmi les quatre espèces décrites chez Loxodontofilaria, une d'hippopotame et trois d'Elephantidae,

L. asiatica Bain, Baker \& Chabaud, 1982, parasite sous-cutané d'Elephas indicus en Birmanie, est l'espèce la plus proche. L. caprini n. sp. s'en distingue par l'œesophage deux fois plus court, la microfilaire deux fois moins longue et à région postérieure enroulée. La prévalence de L. caprini est de 33 \% (sur 112 serows, 37 parasités). Les microfilaires sont dermiques. Cette nouvelle espèce illustre un phénomène majeur dans l'évolution des filaires Onchocercidae, les captures. Celle-ci a pu se faire sur le continent eurasiatique où les Elephantidae et les Rupricaprinii se diversifièrent durant le PlioPleistocène, ou bien après la migration de ces hôtes au Japon.

MOTS CLÉS : Loxondontofilaria caprini n. sp., Onchocercidae, Naemorhedus crispus, serow, Bovidae, Caprinae, élephant, capture, Japon.

\section{INTRODUCTION}

D uring the past ten years, a thorough search for filarial worms found in dermis or subcutaneous tissues of the two wild ruminants, the

* Department of Medical Zoology, Osaka City University Medical School, Osaka 545-8585, Japan.

** Parasitologie Comparée et Modèles Expérimentaux, Associée à l'INSERM (U567), CNRS IFR 101, Muséum National d'Histoire Naturelle, Paris, France.

*:** Department of Environmental Health Science, Faculty of Medicine, Kochi University, Nankoku, Kochi, Japan.

***** Animal Husbandry Research Center, Yamagata-ken Agricultural Co-op, Yamagata, Japan.

**:**: Kitakyushu Museum and Institute of Natural History, Kitakyushu, Japan.

**:***** Department of Veterinary Pathology, Faculty of Applied Biological Science, Gifu University, Japan.

********* Department of Infectious Disease Control, Faculty of Medicine, Oita University, Japan.

Correspondence: Shigehiko Uni.

Tel.: + 81666453760 - Fax: + 81666453762

E-mail: uni@med.osaka-cu.ac.jp serow and the sika deer, in Japan has revealed a rich fauna of 10 endemic filarioids: seven species of Cercopithifilaria Eberhard, 1980, two species of Onchocerca Diesing, 1841, and one species of Cutifilaria Bain \& Schulz-Key, 1974, now reclassified as a subgenus of Mansonella Faust, 1929 (Yagi et al., 1994; Uni et al., 1998a, 1998b, 2001, 2002, and 2004).

We describe a new onchocercid from serows that does not belong to any of these genera and indicate morphologic similarities of the new species to Loxodontofilaria asiatica Bain, Baker \& Chabaud, 1982, a parasite of elephants from Myanmar (Burma).

\section{MATERIALS AND METHODS}

The Japanese serow, Naemorhedus crispus (Temminck, 1845), one member of Caprinae (Bovidae), inhabiting the high mountains, has been protected as a national heritage animal of Japan, and 
its present population is estimated as 50,000 (Uni et al., 1998b). Between 1996 and 2004, in accordance with the conservation and control policies of the Ministry of the Environment, 102 serows were killed on Mt. ZaO $(1,841 \mathrm{~m})$ in Yamagata Prefecture, northern part of Honshu, the largest island of Japan, and nine serows were killed or found dead on Mt. Ena (2,190 m) in Gifu Prefecture, central Honshu. All these animals were dissected at the animal husbandry research center in Yamagata or at Gifu University, and examined for filarial parasites in the skin and subcutaneous connective tissues. In the search for microfilariae, skin snips were taken from the face, ears, neck, olecranons, limbs, back, abdomen, and tail; the number, measurements, and characteristics of the microfilariae found were recorded as described elsewhere (Uni et al., 2002). Blood films were made from each serow and stained with Giemsa's solution, but microfilariae were not found. In addition, limbs and skins of 20 serows from Yamagata and nine from Gifu were shipped refrigerated to the laboratory of Osaka City University Medical School (OCUMS) for detailed examinations.

One serow, found dead on the snow in February 1998 on Mt. Sobo (1,756 m) in Oita Prefecture, Kyushu, the large southern island of Japan, was dissected at the Kitakyushu Museum and Institute of Natural History, Kitakyushu.
Adult worms found were placed in $2 \%$ formalin in saline and the specimens were cleared in lactophenol for study. Measurements are given in Table I: the body length of adult worms in millimeters and the other dimensions in micrometers. Microfilariae taken from female uteri were stained with Giemsa's solution. Scanning electron microscopic (SEM) micrographs of the females and males were prepared as described elsewhere (Uni et al., 2001). The anterior and posterior parts of some worms were used for morphologic study and the midbody specimens of the same worms have been fixed in $100 \%$ ethanol for molecular analysis as in Agatsuma et al. (2005) and Casiraghi et al. (2004).

The generic host name, Naemorhedus, used instead of Capricornis is consistent with Grubb (1993). The authorities of the new species are Uni and Bain.

\section{RESULTS}

LOXODONTOFILARIA CAPRINI UNI \& BAIN, N. SP. (Tables I, II; Figs 1-11)

Dilarioidea, Onchocercidae (Leiper, 1911) Chabaud 1 \& Anderson, 1959, Onchocercinae Leiper, 1911; Loxodontofilaria Berghe \& Gillain, 1939. Large nematodes $210-275 \mathrm{~mm}$ long in females, $110-150 \mathrm{~mm}$

\begin{tabular}{|c|c|c|c|c|c|}
\hline & L. caprini n. sp. & L. loxodontis & L. gossi & L. asiatica & L. bippopotami \\
\hline $\begin{array}{l}\text { Host genus } \\
\text { Host species } \\
\text { Parasitic location } \\
\text { Locality }\end{array}$ & $\begin{array}{l}\text { Naemorbedus } \\
\text { crispus } \\
\text { subcutaneous } \\
\text { Japan }\end{array}$ & $\begin{array}{l}\text { Loxodonta } \\
\text { africana } \\
\text { subcutaneous } \\
\text { Zaire }\end{array}$ & $\begin{array}{l}\text { Loxodonta } \\
\text { africana } \\
\text { "stomach" } \\
\text { Tanganyika }\end{array}$ & $\begin{array}{l}\text { Elephas } \\
\text { indicus } \\
\text { subcutaneous } \\
\text { Myanmar (Burma) }\end{array}$ & $\begin{array}{l}\text { Hippotamus } \\
\text { amphibius } \\
\text { subcutaneous } \\
\text { South Africa }\end{array}$ \\
\hline $\begin{array}{l}\text { Females } \\
\text { Body length } \\
\text { Width at midbody } \\
\text { Buccal cavity } \\
\text { Nerve ring* } \\
\text { Deirids* } \\
\text { Esophagus } \\
\text { Vulva* } \\
\text { Ovejector } \\
\text { Tail }\end{array}$ & $\begin{array}{l}\text { SW1-30 (n= 10) } \\
240(210-275)[243] \\
370(360-490)[412] \\
3(1-4)[3] \\
280(280-420)[346] \\
\text { ND }(346-630)[523] \\
1,450(1,070-1,530)[1,406] \\
1,825(1,400-2,110)[1,817] \\
560(400-560)[479] \\
420(250-480)[387]\end{array}$ & $\begin{array}{l}155 \\
320 \\
- \\
276 \\
- \\
1,800 \\
920 \\
1,680 \\
380\end{array}$ & $\begin{array}{l}115-136 \\
900 \\
- \\
250 \\
- \\
1,550-1,750 \\
3,240-4,050 \\
\text { long } \\
230\end{array}$ & $\begin{array}{l}180-190 \\
295-420 \\
- \\
380-440 \\
700,760,820 \\
2,600-2,740 \\
1,300-1,550 \\
630 \\
320-350\end{array}$ & $\begin{array}{l}90-95 \\
375-480 \\
6 \\
380 \\
860 \\
2,550-2,800 \\
1,300 \\
1,600 \\
480-530\end{array}$ \\
\hline $\begin{array}{l}\text { Microfilariae } \\
\text { Body length } \\
\text { Body width }\end{array}$ & $\begin{array}{l}(\mathbf{n}=\mathbf{1 5}) \\
123-125(105-140)[121] \\
6-8(5-8)[6]\end{array}$ & $\begin{array}{l}180-200 \\
6.5-7.0\end{array}$ & $\begin{array}{l}275 \\
-\end{array}$ & $\begin{array}{l}248-252 \\
5.5\end{array}$ & $\begin{array}{l}355-380 \\
9-10\end{array}$ \\
\hline $\begin{array}{l}\text { Males } \\
\text { Body length } \\
\text { Width at midbody } \\
\text { Nerve ring* } \\
\text { Deirids* } \\
\text { Esophagus } \\
\text { Right spicule } \\
\text { Left spicule } \\
\text { Tail }\end{array}$ & $\begin{array}{l}\text { SW1-6 (n= 10) } \\
120(110-150)[130] \\
260(230-270)[249] \\
300(220-350)[293] \\
\text { ND }(415-515)[453] \\
1,300(1,010-1,300)[1,176] \\
175(140-175)[159] \\
410(340-420)[374] \\
270(220-300)[261]\end{array}$ & & & & \\
\hline
\end{tabular}

Holotype (SW1-30) and allotype (SW1-6) of L. caprini n. sp. are presented first, followed by range and then means.

Unit: see text. * From anterior end. n: number of parasites examined. ND: not done. - Not reported.

Table I. Measurements of adults and microfilariae of Loxodontofilaria caprini n. sp. and other species. 


\begin{tabular}{|c|c|c|c|c|c|c|c|c|c|}
\hline Serow ID no. & Face & Ears & Neck & $\begin{array}{c}\text { Thoracic } \\
\text { limbs }\end{array}$ & Olecranons & Midback & Abdomen & $\begin{array}{l}\text { Pelvic } \\
\text { limbs }\end{array}$ & Tail \\
\hline 1 & - & - & + & - & ND & - & + & - & - \\
\hline 3 & - & - & + & - & ND & + & - & - & - \\
\hline 8 & - & - & + & - & ND & - & - & - & - \\
\hline 15 & - & - & +++ & - & - & + & + & - & - \\
\hline 17 & - & - & ++ & - & - & - & +++ & + & - \\
\hline 20 & - & - & ++ & - & + & + & - & + & + \\
\hline 24 & - & - & + & - & + & - & - & - & - \\
\hline $01-1$ & - & - & + & - & + & ++ & + & - & + \\
\hline $02-1$ & - & - & +++ & - & - & + & + & - & - \\
\hline C1 & ND & - & ND & ++ & ND & + & + & - & +++ \\
\hline YG2 & + & - & + & - & ND & + & - & - & - \\
\hline YG3 & ND & - & +++ & - & ND & + & + & - & + \\
\hline Total & 1 & 0 & 11 & 1 & 3 & 8 & 7 & 2 & 4 \\
\hline Detection rate & $(1 / 10)$ & 0 & $(11 / 11)$ & $(1 / 12)$ & $(3 / 6)$ & $(8 / 12)$ & $(7 / 12)$ & $(2 / 12)$ & $(4 / 12)$ \\
\hline
\end{tabular}

Number of microfilariae: (-) not found; (+) 1-9; (++) 10-19; (+++) 20 or more; ND: not done.

Table II. - Distribution of microfilariae of Loxodontofilaria caprini n. sp. in skin snips of Japanese serows with such microfilariae.

long in males (Table I). Cephalic extremity attenuated, rounded (Fig. 1A). External labial papillae in rectangle elongated dorsoventrally, cephalic papillae in laterally elongated rectangle, amphids anterior to labial papillae (Figs 1B and 3). Mouth small, shallow buccal cavity from 1 to $4 \mu \mathrm{m}$ high, lined by thin cuticular lamina between the peribuccal cuticle and esophagus (Fig. 1C-D). Deirids posterior to nerve ring, with one or two points each (Figs 1A, 1E, and 4). Esophagus undivided, lumen with Y-shaped in transverse section (Fig. 1A).

Thick cuticle $(8-20 \mu \mathrm{m})$ composed of two or three layers (Figs 1G-H and 5): external layer with marked striae (10 $\mu \mathrm{m}$ apart in female; $6 \mu \mathrm{m}$ apart in male), oblique in lateral fields (Fig. 8), median layer thicker in posterior part, with internal striae.

Female ( 45 complete and 32 fragment specimens): vulva close to esophagointestinal junction, in slight prominence (Fig. 1A). Vagina subspherical, flat vaginal chamber with sphincter composed of two to three elongated epithelial cells, a bend, and then short unpaired ovejector directed posteriorly, $0.5 \mathrm{~mm}$ long (Table I; Fig. 1F). Opisthodelphy (uteri parallel, directed posteriad). Tail, three times as long as wide, bent dorsally (Fig. 1J); caudal extremity with three round lappets (Figs 1K-M and 6); phasmids at bases of two lateral lappets (Figs $1 \mathrm{M}$ and 6 , arrows).

Microfilariae: No sheath on microfilariae taken from uteri or skin; short cephalic space, inconspicuous cephalic hook, posterior region coiled in almost all microfilariae (Figs 1N and 7); tail extremity attenuated with smooth point. In five uterine microfilariae stained with Giemsa's solution, body length, 105-110 $\mu \mathrm{m}$, width $7.5 \mu \mathrm{m}$; from anterior end, nerve ring 30-35 $\mu \mathrm{m}$ : 29$32 \%$ of body length, excretory pore $45-50 \mu \mathrm{m}$ : $43-45 \%$ of body length, tail 18-20 $\mu \mathrm{m}$ long.

Male (39 complete and 35 fragment specimens): Apex of testis from $1.5 \mathrm{~mm}$ to $25.5 \mathrm{~mm}$ from head. No area rugosa in the posterior part; caudal part slightly coiled (Fig. 2I). Caudal papillae: one median precloacal papilla, four pairs of precloacal papillae (numbered 1 to 4 in Fig. 2G, as in Chabaud \& Petter, 1961); joined papillae (no. 5), just posterior to cloaca on median line, pair no. 6 with spine as shown in figure 10 by SEM, pair no. 7 quite small, and pair no. 8 at mid-length of tail. Terminal group of two pairs (nos 9 and 10): one submedian and the other more lateral. Thus, basically 10 pairs of papillae, but in some specimens a few papillae were atrophied. Caudal extremity with three short triangular lappets and phasmids at their ventral bases (Figs 2G-H and 11, arrows). Spicules (Fig. 2F), stout, unequal: right spicule simple, distal extremity rounded (Fig. 2J); left spicule with handle and lamina of equal length, distal extremity membranous and sharp (Fig. 2K-K-1).

Regarding the prevalence and distribution of adult worms and microfilariae of L. caprini n. sp., 37 (33\%) of 112 serows examined in Japan (36 of 102 from Yamagata; the one from Oita) were infected with adult worms of the new filarioid. Infection was often heavy, reaching 24 worms per animal (SW1) in Yamagata. Many adult worms were found in the subcutaneous tissues of the limbs, mainly the pelvic limbs; a few worms in the neck and trunk. Many microfilariae were found in the skin of the neck, midback, and abdomen, but none in the ears (Table II).

\section{TAXONOMIC SUMMARY}

Type host: Neamorhedus crispus (Temminck, 1845), Caprinae, Bovidae, Japanese serow.

Location in host: adult worms in the subcutaneous connective tissues, mainly of limbs; microfilariae in the skin, mainly of the neck.

Type locality: Mt. Zao, Yamagata Prefecture, northern part of Honshu, Japan. 

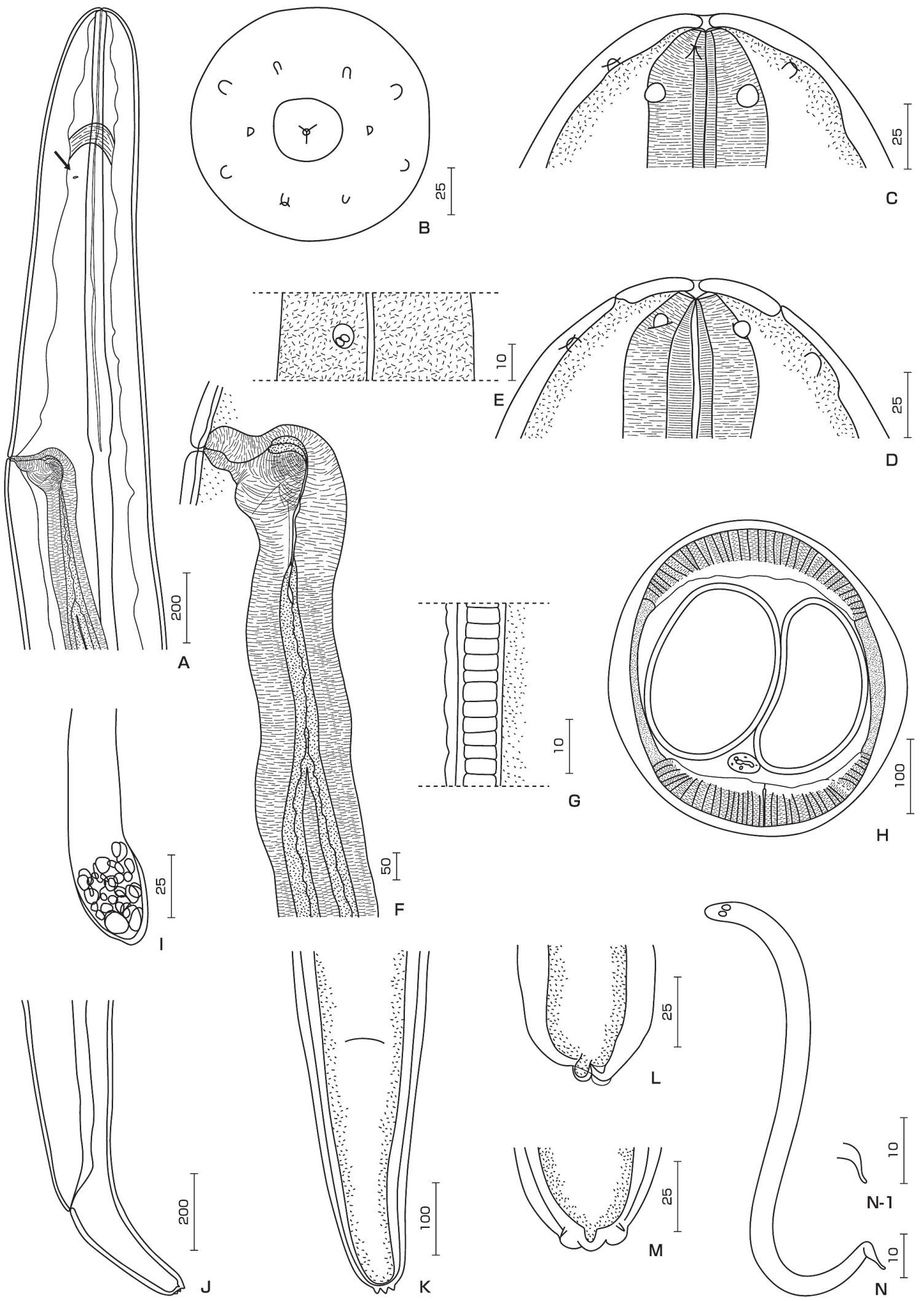

Fig. 1. - Loxodontofilaria caprini n. sp. A-M. Females. A. Anterior part, left lateral view. B. Head, en face view. C. Head, lateral view. D. Head, median view. E. Deirid, median view. F. Vagina and ovejector. G. Cuticle, longitudinal section. H. Transverse section of the midbody, cuticular thickening at the lateral areas. I. Posterior end of the ovary. J. Posterior part, left lateral view. K. Posterior part, ventral view. L. Caudal end, lateral view. M. Caudal end, median view. N-N-1. A microfilaria from the ovejector. N. Microfilaria with coiled posterior end. N-1. Posterior end of the microfilaria. Bars, micrometers. 


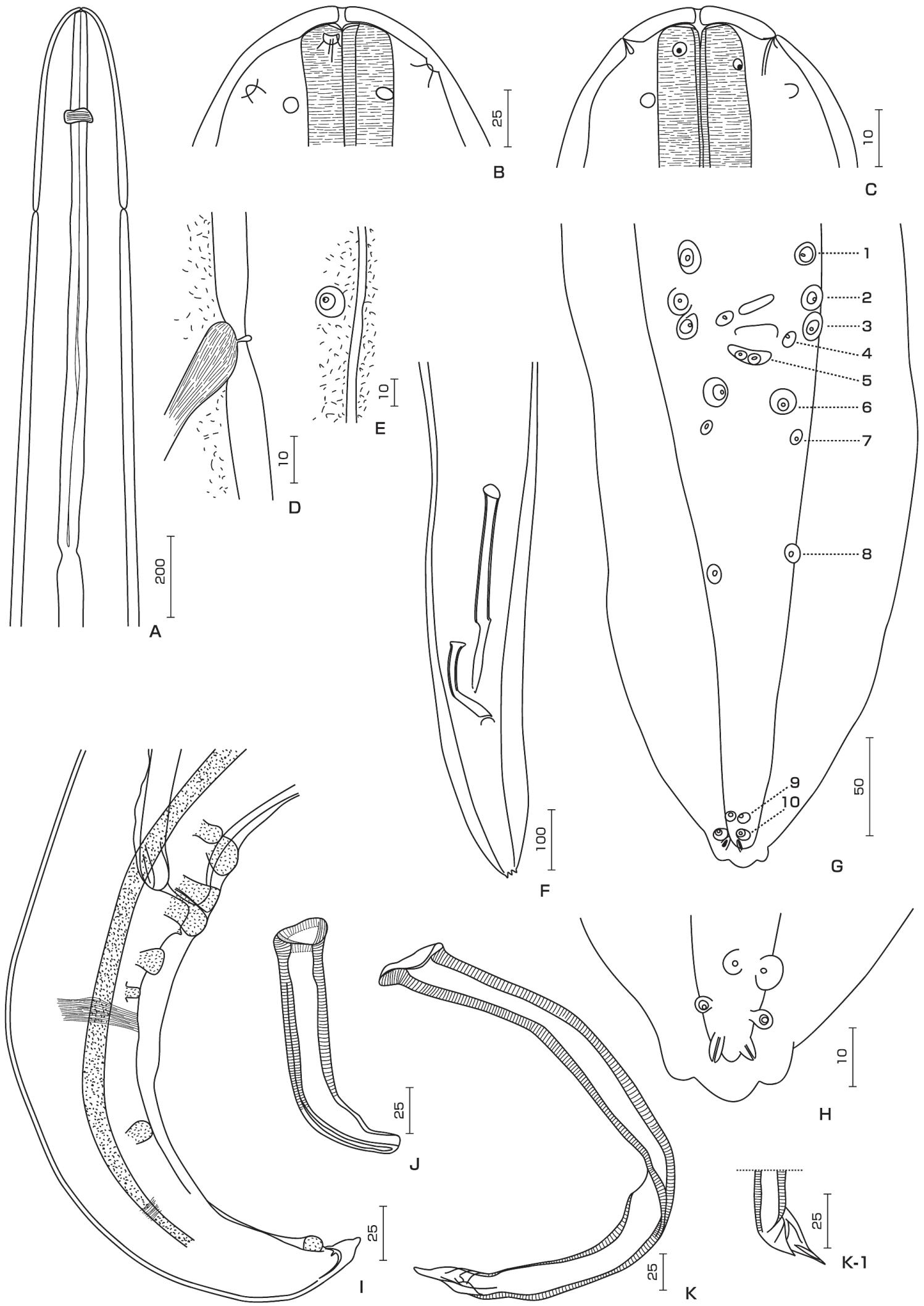

Fig. 2. - L. caprini n. sp. A-K-1. Males. A. Anterior part, median view. B. Head, lateral view. C. Head, median view. D. Deirid, lateral view. E. Deirid, median view. F. Posterior part showing spicules, ventral view. G. Posterior part showing caudal papillae, ventral view. About papillae number, see text. H. Caudal end, ventral view. I. Posterior part, right lateral view. J. Right spicule, right lateral view. K. Left spicule, left lateral view. K-1. Posterior end of the left spicule, vental view. Bars, micrometers. 


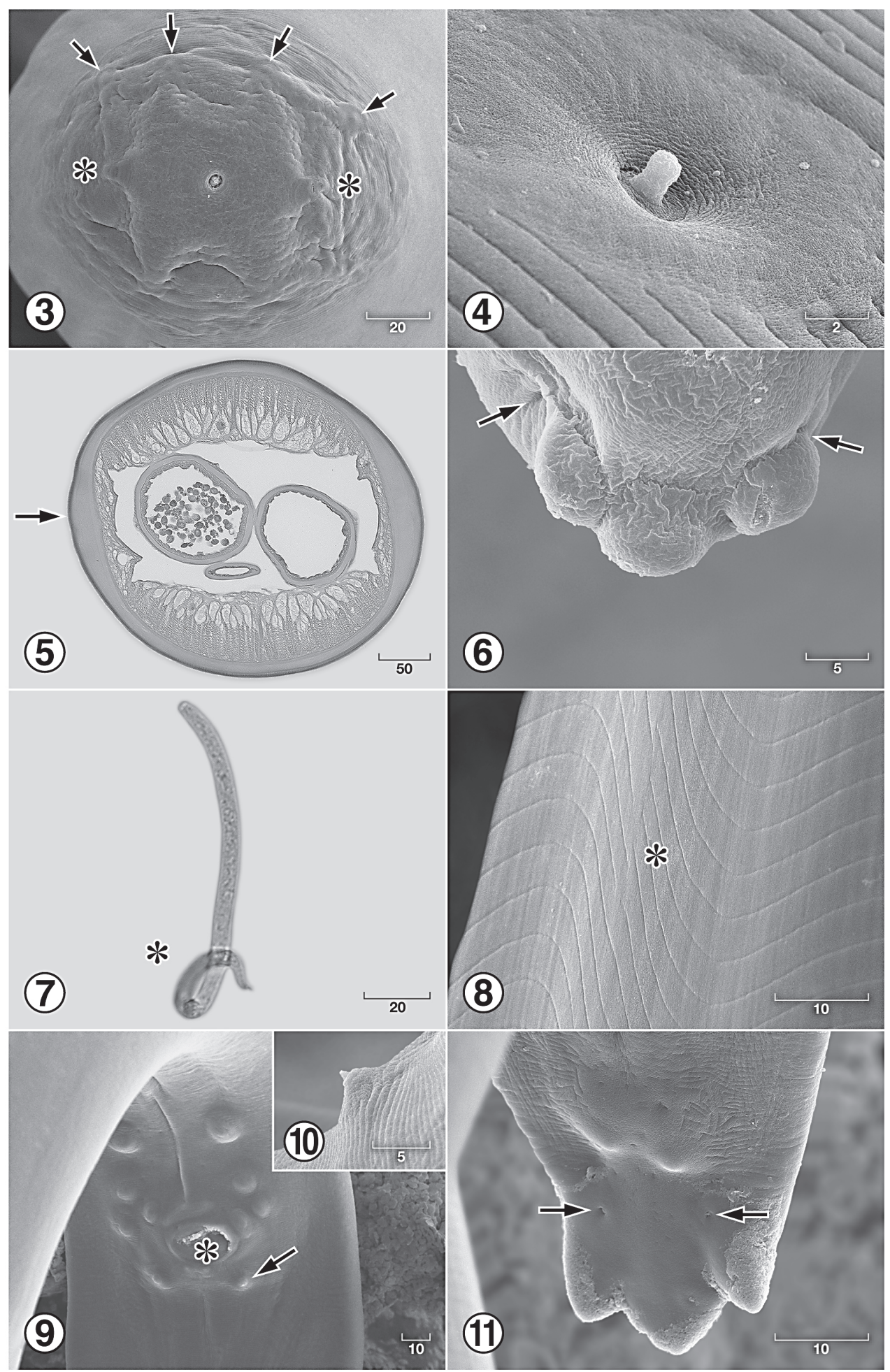

Fig. 3. - SEM of anterior end of a female L. caprini n. sp., amphids (*) and papillae (arrows). Bar, micrometers.

Fig. 4. - SEM of deirid of a female L. caprini n. sp. Bar, micrometers.

Fig. 5. - Transverse section of a female L. caprini n. sp. Lateral thickening of the cuticle (arrow). Bar, micrometers.

Fig. 6. - SEM of posterior end of a female L. caprini n. sp. with phasmidial pores (arrows) and three round lappets. Bar, micrometers. Fig. 7. - Microfilaria taken from ovejector of a female L. caprini n. sp. seen by differential interference contrast microscopy. Coiled posterior end $(*)$. Bar, micrometers.

Fig. 8. - Oblique striations $\left(^{*}\right)$ in the lateral field of the midbody of a male L. caprini $\mathrm{n}$. sp. Bar, micrometers.

Fig. 9. - SEM of papillae around the cloaca $(*)$ in a male L. caprini n. sp. Pair (no. 6) of papillae (arrow). Bar, micrometers.

Fig. 10. - SEM of the spine of papilla (pair no. 6) in a male L. caprini n. sp. Bar, micrometers.

Fig. 11. - Caudal end of a male L. caprini n. sp. with phasmidial pores (arrows) and three conical lappets. 
Collection dates: type specimens on 18 June 2002; other specimens between 16 February 1997 and 25 December 2004 .

Specimens deposited: female holotype (SW1-30) and male allotype (SW1-6); collection number $124 \mathrm{JW}$, the Muséum National d'Histoire Naturelle (MNHN), Paris. Paratype: three males (SW1-5, SW1-PL15, and SW1-PL17), $126 \mathrm{JW}$, MNHN; two males (SW1-PL11 and SW1-PL12) in the Department of Medical Zoology, Osaka City University Medical School (OCUMS). Other specimens: two females (YG2-5 and YG2-18) and one male (YG2-11), $125 \mathrm{JW}$ in MNHN; 141 specimens in OCUMS.

Etymology: we named this species L. caprini $\mathrm{n}$. sp. to illustrate the zoologic host group.

\section{DISCUSSION}

U pon dissection of the serows, L. caprini n. sp. resembled Onchocerca suzukii Yagi, Bain \& Shoho 1994, which is a large filarioid without transverse ridges in either sex, found in the subcutaneous connective tissues of serows. However, the new parasite appeared to belong to the genus Loxondontofilaria Berghe \& Gillain, 1939 on the basis of the following characteristics: complex vagina in females, well-developed esophagus with shallow buccal cavity, and long tail with three caudal lappets (Bain et al., 1982). The genus presently comprises three species from the Elephantidae (Proboscidea) and one species from the hippopotamus (Suiformes), which has been tentatively assigned to Loxodontofilaria on the basis of characteristics of the female worms only, as the first male worm in the genus Loxodontofilaria is described herein, L. caprini n. sp. The type species, L. loxodontis Berghe \& Gillain, 1939 is a subcutaneous parasite of the African elephant, Loxodonta africana (Blumenbach) in Zaire (Berghe \& Gillain, 1939). The species is distinct from L. caprini $\mathrm{n}$. sp. in the body dilation at the level of the vulva, the vulva at mid-length of the esophagus, the vulva anterior to (half as close to the head as) that of L. caprini n. sp. (Table I), the vagina with three bends (described as V-shape), the ovejector three times longer, and the longer microfilariae.

Loxodontofilaria gossi (Baylis, 1923), a parasite of L. africana in Tanganyika, has a visceral location (probably the peritoneal cavity, assumed by Baylis, 1923). The species differs from our material by the twice-aswide body, the vulva far behind the esophagointestinal junction (Table I), the vagina with a distinct posterior spherical prominence, the lumen with three bends (described as V-shape), the tail bent ventrally and shorter, and longer microfilaria.

Loxodontofilaria asiatica Bain, Baker \& Chabaud, 1982 from the subcutaneous tissue of Elephas indicus Linnaeus in Myanmar (Burma), resembles L. caprini n. sp. with a similar distance between head and vulva, the vaginal anatomy, the length of the ovejector, and the tail bent dorsally. However, the species differs from L. caprini $\mathrm{n}$. sp., possessing a longer esophagus (Table I), tiny lateral caudal lappets, and the microfilariae being twice as long as those of $L$. caprini $\mathrm{n}$. sp. In L. caprini n. sp., the microfilariae coiled posteriorly.

Loxodontofilaria hippopotami (Leiper, 1910) Bain, Baker \& Chabaud, 1982, a subcutaneous filaria taken from Hippopotamus amphibius Linnaeus, was first described from Uganda, and redescribed by Bain et al. (1982) from material collected in South Africa. The species was distinct from our material with several characteristics: shorter body (Table I), divided and longer esophagus, larger microfilaria, and simpler anatomy of the vagina without any bends.

On the three species of Loxodontofilaria parasitic in the Elephantidae, the closest species to L. caprini n. sp. is L. asiatica, a parasite of Elephas indicus in Asia, as assessed according to the anatomy of the vagina: in L. asiatica and L. caprini n. sp., the chamber has only one bend as opposed to three bends in L. loxodonta and L. gossi, the parasites of Loxodonta africana in the Ethiopian region. The new filarioid species of serows provided the first description of the male worm in the genus Loxondotofilaria. The 10 pairs of caudal papillae in the male and deirids, well-developed esophagus, and caudal lappets in both sexes exemplify primitive characteristics of the genus. However, atrophy of the buccal capsule appears to be a derived characteristic (Bain et al., 1982). The "zoologically incoherent" host range (Chabaud, 1982) of Loxodontofilaria, composed of elephants, serows (Caprinae) and, perhaps, hippopotami, suggests the existence of "captures" or the host-switching. That these events are central in the evolution of onchocercid filariae has been supported repeatedly (Chabaud \& Bain, 1994). Litomosoides Chandler, 1931 and Cercopithifilaria Eberhard, 1980 are excellent examples (Guerrero et al., 2002; Bain et al., 2002). The present filarioid of the serows is a new example.

The diversity of Loxodontofilaria is likely underestimated as no investigation has been made into any other rupicaprine, which are spread throughout the world, and the majority of elephantids are extinct. However, on the basis of the host histories we hypothesize that the hostswitching could have occurred during the PliocenePleistocene. During that period in Eurasia, Elephantidae animals were numerous and diversified (Todd \& Roth, 1996) and the young rupicaprine lineage radiated (Geist, 1987; Soma et al., 1987). The host-switching might have occurred on the Continent or, later, on the Japanese islands after migrations of Naemorhedus ancestors into the Japanese main islands (Honshu, Shikoku, and Kyushu except for Hokkaido) during the middle Pleistocene, 0.7-0.1 Ma (Dobson \& Kawamura, 1998). According to Takahashi \& Namatsu (2000) on the origin of 
Japanese elephants, Palaeoloxodon naumanni (Makiyama, 1924) migrated from continental Asia to the Japanese islands by the southern route in the middle Pleistocene (0.3 Ma), and Mammuthus primigenius (Blumenbach, 1799) migrated from continental Asia to Hokkaido by the northern route in the late Pleistocene (0.13-0.03 Ma). The exiguity of emerged territories and local diversification of elephants may be considered as favorable factors for the host-switching. L. caprini n. sp. could be a relict of the filarial fauna hosted by Japanese elephants during the Pleistocene.

\section{ACKNOWLEDGEMENTS}

W e thank Dr. K. Takahashi, Lake Biwa Museum, Shiga, for suggestions about the migration of elephants; Mr. T. Kenkou of the Central Laboratory of Osaka City University Medical School for the histologic preparation, and $\mathrm{Mr}$. H. Nakagawa of the same laboratory for SEM examination of the parasites. We are grateful to Prof. M. Iseki, Kanazawa University, for his part in the financial support for this study and Mr. J. Yohay for reading the manuscript. This study was partly supported by grants for the overseas research program of Osaka City University and by the Muséum National d'Histoire Naturelle, Paris, where S. Uni, as a visiting researcher, collaborated with $\mathrm{O}$. Bain between July and September, 2005.

\section{REFERENCES}

Agatsuma T., Iwagami M., Uni S., TakaOKa H., Katsumi A., Kimura E. \& Bain O. Molecular phylogenetic relationships among seven Japanese species of Cercopithifilaria. Parasitology International, 2005, 54, 195-199.

Bain O., BAKer M. \& Chabaud A.G. Nouvelles données sur la lignée Dipetalonema (Filarioidea, Nematoda). Annales de Parasitologie Humaine et Comparée, 1982, 57, 593-620.

BAIN O., Uni S. \& TAKaOKA H. A synthetic look at a twenty years old taxon, Cercopithifilaria; its probable evolution. Proceedings of the $10^{\text {th }}$ International Congress of Parasitology (ICOPA X), Vancouver, Canada, 2002, Monduzzi Ed., Medimond Inc., Bologna, Italy, 365-368.

Baylis M.A. A filariid from the African elephant. Annals and Magazine of Natural History, (Series 9), 1923, 11, 208-211.

Berghe L. VAN DEN \& Gillain G.R. Sur un genre nouveau de Filaroidea chez l'Eléphant au Congo belge. Revue de Zoologie et Botanique Africaines, 1939, 32, 388-393.

Casiraghi M., Bain O., Guerrero R., Martin C., Pocacqua V., Gardner S.L., Franceschi A. \& BAndi C. Mapping the presence of Wolbachia pipientis on the phylogeny of filarial nematodes: evidence for symbiont loss during evolution. International Journal for Parasitology, 2004, 34, 191-203.

Chabaud A.G. Spectre d'hôtes et évolution des nématodes parasites de vertébrés, in: $2^{\text {ème }}$ Symposium sur la Spécificité Parasitaire des Parasites de Vertébrés. 1981. Mémoires du Muséum Natonal d'Histoire Naturelle, Série A, Zoologie, 1982, 123, 73-76.

Chabaud A.G. \& Bain O. The evolutionary expansion of the Spirurida. International Journal for Parasitology, 1994, 24, 1179-1201.

Chabaud A.G. \& Petter A.J. Remarques sur l'évolution des papilles cloacales chez les nématodes phasmidiens parasites de vertébrés. Parassitologia, 1961, 3, 51-70.

Dobson M. \& KaWAmura Y. Origin of the Japanese land mammal fauna: allocation of extant species to historicallybased categories. Quaternary Research, 1998, 37, 385-395.

GeIsT V. On the evolution of the Caprinae, in: The Biology and Management of Capricornis and Related Mountain Antelopes. Soma H. (ed), Croom Helm, London, 1987, 3-40.

GrubB P. Oder Artiodactyla, in: Mammal Species of the World: a Taxonomic and Geographic Reference. $2^{\text {nd }}$ ed., Wilson D.E. \& Reeder D.M. (eds), 1993, Smithsonian Institution Press, Washington, D.C., 406-407.

Guerrero R., Martin C., Gardner S.L. \& Bain O. New and known species of Litomosoides (Nematoda: Filarioidea): important adult and larval characters and taxonomic changes. Comparative Parasitology, 2002, 69, 177-195.

Soma H., Kada H. \& Matayoshi K. Evolutionary pathways of karyotypes of the tribe Rupicaprini, in: The Biology and Management of Capricornis and Related Mountain Antelope. Soma H. (ed), Croom Helm, London, 1987, 62-71.

TAKahashi K. \& Namatsu K. Origin of the Japanese Proboscidea in the Plio-Pleistocene. Earth Science, 2000, 54, 257-267.

TODD N.E. \& Roth V.L. Origin and radiation of the Elephantidae, in: The Proboscidea: Evolution and Palaeoecology of Elephants and their Relatives. Shoshani J. \& Tassy P. (eds), Oxford University Press, Oxford, 1996, 193202.

Uni S., Bain O. \& TAKaOKa H. Affinities between Cutifilaria (Nematoda: Filarioidea), parasite of deer, and Mansonella as seen in a new onchocercid, $M$. (C.) perforata n. sp., from Japan. Parasite, 2004, 11, 131-140.

Uni S., Bain O., Takaoka H., Katsumi A., Fujita H. \& SuZuki Y. Diversification of Cercopithifilaria species (Nematoda: Filarioidea) in Japanese wild ruminants with description of two new species. Parasite, 2002, 9, 293-304.

Uni S., SuZuki Y., Baba M., Mitani N., TaKaOKa H., Katsumi A. \& BaIn O. Coexistence of five Cercopithifilaria species in the Japanese rupicaprine bovid, Capricornis crispus. Parasite, 2001, 8, 197-213.

Uni S., Suzuki Y. \& Katsumi A. Cercopithifilaria shoboi n. sp. (Nematoda: Filarioidea) from the relict Bovidae, Capricornis crispus, in Japan. Parasite, 1998a, 5, 119-126.

Uni S., Suzuki Y., Katsumi A., Kimata I., Iseki M. \& Bain O. Taxonomy and pathology of filarial parasites from Japanese serows (Capricornis crispus). Proceedings of $9^{\text {th }}$ International Congress of Parasitology (ICOPA IX), Chiba, Japan, Monduzzi Ed., Bologna, Italy, 1998b, 681-684.

YAGI K., BaIN O. \& SHOHO C. Onchocerca suzukii n. sp. and O. skrjabini (= O. tarsicola) from a relict bovid, Capricornis crispus, in Japan. Parasite, 1994, 1, 349-356.

Reçu le 8 avril 2006 Accepté le 11 juillet 2006 